\title{
Pengaruh Ukuran Perusahaan, Earning Per Share dan Return On Asset terhadap Nilai Perusahaan Sub Sektor Makanan dan Minuman yang Terdaftar di Bursa Efek Indonesia Tahun 2016 - 2018
}

\author{
Cheltis Carles Kehek ${ }^{1 *}$, Wayan Cipta², Ni Made Suci ${ }^{3}$ iD \\ ${ }^{123}$ Program Studi Manajemen, Fakultas Ekonomi, Universitas Pendidikan Ganesha, Singaraja, Indonesia \\ * charleskehek99@gmail.com ${ }^{1 *}$
}

\begin{abstract}
Abstrak
Penelitian ini bertujun untuk menguji pengaruh ukuran perusahaan, earning per share dan return on asset terhadap nilai perusahaan sub sektor makanan dan minuman yang terdaftar di Bursa Efek Indonesia tahun 2016 - 2018 baik secara simultan maupun secara parsial. Populasi yang digunakan dalam penelitian ini adalah perusahaan sub sektor makanan dan minuman yang terdaftar di Bursa Efek Indonesia periode 2016 - 2018 sebanyak 11 perusahaan. Desain penelitian yang digunakan adalah kuantitatif kausal. Data dikumpulkan dengan pencatatan dokumen, serta dianalisis dengan analisis regresi linier berganda. Hasil penelitian ini menunjukkan bahwa: (1) ukuran perusahaan, earning per share, dan return on asset berpengaruh signifikan terhadap nilai perusahaan.(2) ukuran perusahaan secara parsial berpengaruh positif dan signifikan terhadap nilai perusahaan. (3) Earning per share berpengaruh negatif dan signigifikan terhadap nilai perusahaan. (4) Return on asset berpengaruh positif dan signifikan terhadap nilai perusahaan.
\end{abstract}

Kata Kunci : Earning Per Share, Nilai Perusahaan, Retur On Asset Dan Ukuran Perusahaan

\section{Abstract}

This study aims to examine the effect of company size, earnings per share and return on assets on the value of the food and beverage sub-sector companies listed on the Indonesia Stock Exchange in 2016 - 2018 either simultaneously or partially. The population used in this research is the food and beverage sub sector companies listed on the Indonesia Stock Exchange for the period 2016 - 2018 as many as 11 companies. The research design used is quantitative causal. Data were collected by recording documents, and analyzed by multiple linear regression analysis. The results of this study indicate that: (1) company size, earnings per share, and return on assets have a significant effect on firm value .(2) company size partially has a positive and significant effect on firm value.(3) Earning per share has a negative and significant effect on firm value. (4) Return on assets has a positive and significant effect on firm value

Keywords: Earnings Per Share, Firm Value, Returns On Assets And Company Size

\section{Pendahuluan}

Sektor industri manufaktur merupakan salah satu industri terpenting yang mampu menjadi daya ungkit bagi peningkatan perekonomian nasional. Menurut Menteri Keuangan Sri Mulyani yang dilansir dari media liputan 6 yang dikeluarkan pada tanggal 11 Juni 2019 bahwa "pertumbuhan ekonomi pada saat ini masih berkisar diangka 5 persen". Menyikapi hal tersebut pemerintah berupaya semaksimal mungkin untuk mendorong peningkatan investasi pada sektor industri terutama yang berorientasi pada hasil ekspor.

Perusahaan manufaktur memiliki peranan penting dalam perdangan internasional, hal tersebut tidak terlepas dari adanya peningkatan terhadap kualitas serta ouput yang dihasilkan oleh perusahaan sehingga mampu bersaing dalam pasar global, khususnya pada sektor industri. barang konsumsi. Manajemen perusahaan industri yang baik sangat membantu

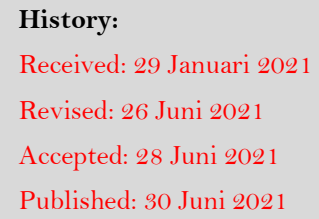


perusahaan untuk lebih memaksimalkan pencapaian hasil produksi yang optimal sehingga mencapai tujuan perusahaan yakni meningkatkan nilai perusahaan yang baik.

Rahayu dan sari (2018) menjelaskan bahwa, ukuran keberhasilan perusahaan dapat dilihat dari sejauh mana perusahaan dapat mensejahterakan para pemegang saham dan memaksimalkan nilai perusahaan yang merupakan tujuan utama bagi perusahaan sebagai upaya menciptakan tren positif dimasa yang akan datang. Nilai perusahaan dapat dilihat dari harga saham dan jumlah saham yang beredar pada akhir periode. Menurut Innafisah dkk (2019) bahwa, nilai perusahaan merupakan sejumlah harga yang bersedia dibayar oleh investor apabila perusahaan tersebut dijual. Nilai perusahaan merupakan persepsi investor terhadap tingkat keberhasilan perusahaan yang sering dikaitkan dengan harga saham. Apabila nilai perusahaan semakin baik maka perusahaan tersebut dapat memaksimalkan dan memberikan kesejahteraan yang baik kepada para pemegang sahamnya.

Dalam penelitian ini menggunakan perusahaan sub sektor makanan dan minuman yang terdaftar di Bursa Efek Indonesia sebagai populasai dan sampel dikarenakan perusahaanperusahaan pada sub sektor ini memiliki rata-rata perhitungan nilai perusahaan yang rendah yakni sebesar $155,83 \%$ dibandingkan dengan beberapa sub sektor lainnya yang memiliki rata-rata cukup tinggi. Meningkatkan nilai perusahaan perlu memerhatikan beberapa faktor untuk menguji pengaruh terhadap nilai perusahaan yaitu ukuran perusahaan, Earning per share dan return on asset.

Ukuran perusahaan adalah suatu bentuk ukuran yang mengklasifikasikan suatu perusahaan menurut besar atau kecilnya yang dilakukan dengan cara mengetahui total aktiva, log size, nilai pasar saham dan lainnya. Hermuningsih (2012), ukuran perusahaan merupakan rata-rata total penghasilan bersih dari operasi perusahaan selama periode tertentu.

Prasetyorini (2013), menjelaskan bahwa semakin besar ukuran atau skala perusahaan maka akan semakin besar peluang perusahaan untuk mendapatkan sumber dana dari berbagai pihak, baik internal maupun dari pihak eksternal sehingga hal ini menjadi potensi pada perusahaan untuk meningkatkan nilai perusahaan. Hasil penelitian sebelumnya yang sejalan dikemukakan oleh Pantow dkk (2015), Mindra dan Erawati (2014), mengungkapkan bahwa, ukuran perusahaan memiliki pengaruh yang positif dan signifikan terhadap nilai perusahaan. Ini berarti skala atau ukuran besar kecilnya suatu perusahaan dapat memiliki pengaruh terhadap nilai perusahaan. Disisi lain berbeda dengan penelitian yang dilakukan oleh Dewi dan Wirajaya (2013) yang menjelaskan bahwa, ukuran perusahaan tidak memiliki pengaruh positif dan tidak signifikan terhadap nilai perusahaan. Ukuran perusahaan pada penelitian ini menggunakan total aset sebagai pengukurannya. Dewi dan Wirajaya (2013), ukuran perusahaan dapat dinyatakan melalui total aset yang dimiliki perusahaan untuk melakukan operasinya.

Menurut Kasmir (2010), earning per share (EPS) merupakan rasio yang digunakan untuk mengukur kemampuan manajemen perusahaan dalam menghasilkan laba per lembar sahamnya dan diberikan kepada pemegang saham atau investor. Rasio EPS menjadi salah satu tolok ukur bagi para investor dalam mengambil keputusan untuk melakukan kegiatan investasi. Investor yang rasional tentu akan memilih saham-saham yang memberikan tingkat keuntungan yang tinggi dengan risiko yang rendah. Kholis dkk (2018) mengungkapkan bahwa, apabila EPS mengalami peningkatan maka nilai perusahaan akan mengalami peningkatan drastis, dan sebaliknya jika EPS mengalami penurunan maka nilai perusahaan juga akan mengalami penurunan drastis. Dalam penelitian ini rasio EPS dapat diukur dengan membandingkan laba bersih yang diperoleh perusahaan dengan jumlah saham yang beredar di pasar (Khairani dan Imelda, 2016).

Return on asset merupakan salah satu rasio yang digunakan untuk mengukur kemampuan perusahaan dalam memperoleh keuntungan dari seluruh aset yang dimilikinya. 
Harahap (2010) menjelaskan bahwa, ROA menggambarkan perputaran aktiva yang diukur dari volume penjualan. Semakin besar ROA maka semakin baik. ROA berfungsi untuk mengukur tingkat pengembalian atas aktiva perusahaan. ROA merupakan salah satu bentuk dari rasio profitabilitas yang dimaksudkan untuk mengukur kemampuan perusahaan. atas keseluruhan dana yang ditanamkan dalam aktivitas yang digunakan untuk operasi perusahaan dengan tujuan menghasilkan laba dengan memanfaatkan aktiva yang dimilikinya. ROA dapat diukur dengan membandingkan laba bersih yang diperoleh perusahaan dengan total aset yang dimilikinya (Harmono, 2016). Berdasarkan teori struktur modal yaitu konsep signaling theory yang mengungkapkan bahwa pencapaian laba yang maksimal akan menjadi sinyal dari manajemen yang menggambarkan prospek perusahaan berdasarkan tingkat laba yang dihasilkan.

Berdasarkan latar belakang dan penelitan terdahulu mengenai hubungan antara ukuran perusahaan, earning per share dan return on asset terhadap nilai perusahaan maka rumusan masalah dalam penelitian ini adalah sebagai berikut: (1) Bagaimana pengaruh ukuran perusahaan, earning pershare dan return on asset (ROA) secara simultan terhadap nilai perusahaan pada perusahaan sub sektor Makanan dan Minuman di Bursa Efek Indonesia. (2) Bagaimana pengaruh ukuran perusahaan, earning per share dan return on asset (ROA) secara parsial terhadap nilai perusahaan pada perusahaan sub sektor Makanan dan Minuman di Bursa Efek Indonesia.

Tujuan penelitian ini adalah untuk mengetahui hal-hal sebagai berikut: (1) Pengaruh dari pada ukuran perusahaan, earning per share dan ROA secara simultan terhadap nilai perusahaan pada perusahaan sub sektor Manakanan dan Minuman di Bursa Efek Indonesia. (2) Pengaruhnya ukuran perusahaan, earning per share dan profitabilitas secara parsial terhadap nilai perusahaan pada perusahaan sub sektor Makanan dan Minuman di Bursa Efek Indonesia.

\section{Hubungan antara Ukuran Perusahaan, Earning Per Share dan Return On Asset terhadap Nilai Perusahaan}

Menurut Musayyana dkk (2019) dalam penelitiannya menyatakan bahwa nilai perusahaan dapat ditingkatkan dengan memaksimalkan size perusahaan, earning per share dan ration on asset dikarenakan apabila ratio tersebut dimaksimalkan dengan baik maka nilai perusahaan akan mengalami peningkatan dan hal tersebut dapat dijadikan sebagai acuan oleh investor untuk melakukan investasi di perusahaan tersebut. hal ini mengandung arti bahwa secara bersama-sama ukuran perusahaan, earning per share dan return on asset berpengaruh terhadap nilai perusahaan. Ukuran perusahaan merupakan gambaran suatu perusahaan dalam mengelola seluruh aktiva yang dimiliki, apabila ukuran perusahaan semakin besar maka dapat mencerminkan tren positif bagi perusahaan yang artinya nilai perusahaan dapat dinilai baik oleh para investor, begitupun juga dengan rasio earning per share dan return on asset apabila kinerja perusahaan berjalan dengan baik dalam mengelola seluruh aktiva dengan baik serta mampu menghasilkan laba dari setiap saham yang dimilikinya maka perusahaan akan memperoleh laba atau keuntungan yang maksimal dan hal ini dapat menjadi citra positif bagi perusahaan serta dapat mensejahterakan pemilik saham.

$H_{1}$ : Terdapat pengaruh ukuran perusahaan, earning per share dan return on asset terhadap nilai perusahaan.

\section{Hubungan antara Ukuran Perusahaan dengan Nilai Perusahaan}

Menurut Riyanto (2001) dalam wahyudi dkk (2016) perusahaan yang berskala besar akan mempunyai peluang yang mudah untuk mengakses kedalam pasar modal untuk 
mendapatkan pendanaan bagi perusahaannya, sehingga rasio pembayaran deviden yang dimiliki perusahaan menjadi lebih tinggi dibandingkan dengan perusahaan yang berskala kecil. Ukuran perusahaan merupakan cerminan total aset yang dimiliki perusahaan, semakin besar perusahaan tersebut maka aset yang dimiliki perusahaan juga semakin besar dan dana yang akan dibutuhkan untuk mempertahankan kegiatan operasionalnya juga akan semakin banyak. Besarnya suatu perusahaan mempengaruhi keputusan yang akan diambil oleh manajemen perusahaan dalam memutuskan pendanaan apa yang akan digunakan oleh perusahaab segingga pendanaan tersebut dapat mengoptimalkan nilai perusahaan. Pratama dan Wiksuana (2016) menjelaskan bahwa besarnya suatu persusahaan menandakan bahwa perusahaan tersebut mengalami perkembangan dan pertumbuhan yang sangat baik sehingga dapat mengoptimalkan nilai perusahaan. Pratama dan Wiksuana (2016) menjelaskan bahwa ukuran perusahaan berpengaruh positif dan siginikan terhadap nilai perusahaan.

\section{$\mathrm{H}_{2}$ : Terdapat pengaruh ukuran perusahaan terhadap nilai perusahaan}

\section{Hubungan Antara Earning Per Share dengan Nilai Perusahaan}

Earning Per Share merupakan keuntungan bersih yang diperoleh perusahaan dari setiap lembar saham yang tersebar di pasar modal. Tentunya semakin besar nilai EPS akan menjadi sinyal positif bagi para pemegang saham dan calon investor lain. Hizkia dkk (2018) mengungkapkan bahwasanya EPS sangat berpengaruh terhadap nilai perusahaan yang mana akan meningkatkan kesejahteraan para pemegang saham serta dapat menarik minat calon investor. Keuntungan yang dimiliki dari setiap lembar saham yang beredar dapat membantu perusahaan dalam meningkatkan nilai suatu perusahaan tersebut. Innafisah dkk (2019) yang menyatakan bahwa rasio erning per share memiliki hubungan yang positif dan signifikan terhadap nilai perusahaan.

\section{$H_{3}$ : Terdapat pengaruh earning per share terhadap nilai perusahaan}

\section{Hubungan Antara Return On Asset Dengan Nilai Perusahaan}

Menurut Hanafi, 2006 (Dalam Helliana dkk, 2015) ROA merupakan rasio profitabilitas yang digunakan perusahaan untuk mengukur tingkat kemampuan perusahaan dalam menghasilkan laba dalam tingkat aset tertentu. Dalam mengukur tingkat efisiensi operasi perusahaan secara keseluruhan, manajemen dapat menggunakan rasio ROA sebagai alat ukur yang pasti. apabila ROA menunjukan hasil yang positif maka perusahaan mampu menghasilkan laba serta mensejahterakan para pemegang saham sehingga hal tersebut dapat memaksimalkan nilai perusahaan menjadi baik. Hal ini didukung oleh Penelitian yang dilakukan oleh Hizkia dkk (2018), mengungkapkan bahwa ROA memiliki hubungan yang positif dan signifikan terhadap nilai perusahaan. Yang artinya bahwa setiap kenaikan ROA akan berdampak baik terhadap kenaikan nilai perusahaan.

$\mathrm{H}_{4}$ : Terdapat pengaruh return on asset terhadap nilai

\section{Metode}

Metode yang digunakan dalam penelitian ini merupakan metode penelitian kuantitatif kausal. Yang mana metode kuantitatif kausal ini digunakan sebagai pembuktian hubungan sebab akibat atau pengaruh yang terdapat pada variabel-variabel dalam penelitian ini. Subjek yang digunakan dalam penelitian adalah perusahaan sub sektor makanan dan minuman yang terdaftar di Bursa Efek Indonesia tahun 2016-2018. Objek dalam penelitian ini menggunak ukuran perusahaan, earning per share, return on asset dan nilai perusahaan.

Dalam penelitian ini teknik pengumpulan data yang digunakan adalah teknik pencatatan dokumen dengan mengunduh laporan tahunan yang dipublikasikan oleh perusahaan terkait yang dimuat dalam Statistic Indonesia Stock Exchange (IDX). Data yang 
digunakan dalam penelitian ini merupakan data yang memiliki keterkaitan langsung yang diperoleh dari laporan keuangan yang memiliki hubungan dalam permasalahan yang akan dibahas yaitu data mengenai ukuran perusahaan, earning per share, retun on asset dan nilai perusahaan yang diperoleh dari perusahaan yang tergolong dalam perusahaan sub sektor makanan dan minuman yang terdaftar di Bursa Efek Indonesia. Data laporan keuangan yang diperoleh merupakan data yang berupa neraca dan laporan laba/rugi pada perusahaan sub sektor makanan dan minuman tahun 2016 - 2018.

Teknik analisis data pada penelitian ini menggunakan teknik analisis regresi linier berganda. Sulistiyono dan Sulistiyowati (2017) menjelaskan bahwa, metode regresi linier merupakan teknik analisis yang memiliki fungsi untuk menjelaskan hubungan antara variabel bebas dan variabel terikat yang memiliki potensi hubungan sebab akibat. Metode pengolahan data dalam penelitian ini menggunakan program SPSS (Statist/ical Product and Service Solution) versi 26.0 for windows. Analisis data dalam penelitian ini dilakukan secara kuantitatif dengan tahapan antara lain: (1) Uji Asumsi klasik, (2) analisis regresi linier berganda dan (3) koefisien determinasi. Teknik analisis ini digunakan dengan tujuan mengetahui adanya hubungan antara variabel bebas dan terikat, kemudian menetapkan tingkat signifikansi serta akan diakhiri dengan penarikan kesimpulan yang didasarkan pada penerimaan atau penolakan terhadap hipotesis.analysis

\section{Hasil dan Pembahasan}

Model analisis yang digunakan digunakan dalam penelitian ini adalah regresi linier berganda dengan bantuan SPSS 26.0. Maka diperoleh struktur hubungan pengaruh ukuran perusahaan, earning per share dan return on asset terhadap nilai perusahaan seperti Gambar 1 berikut.

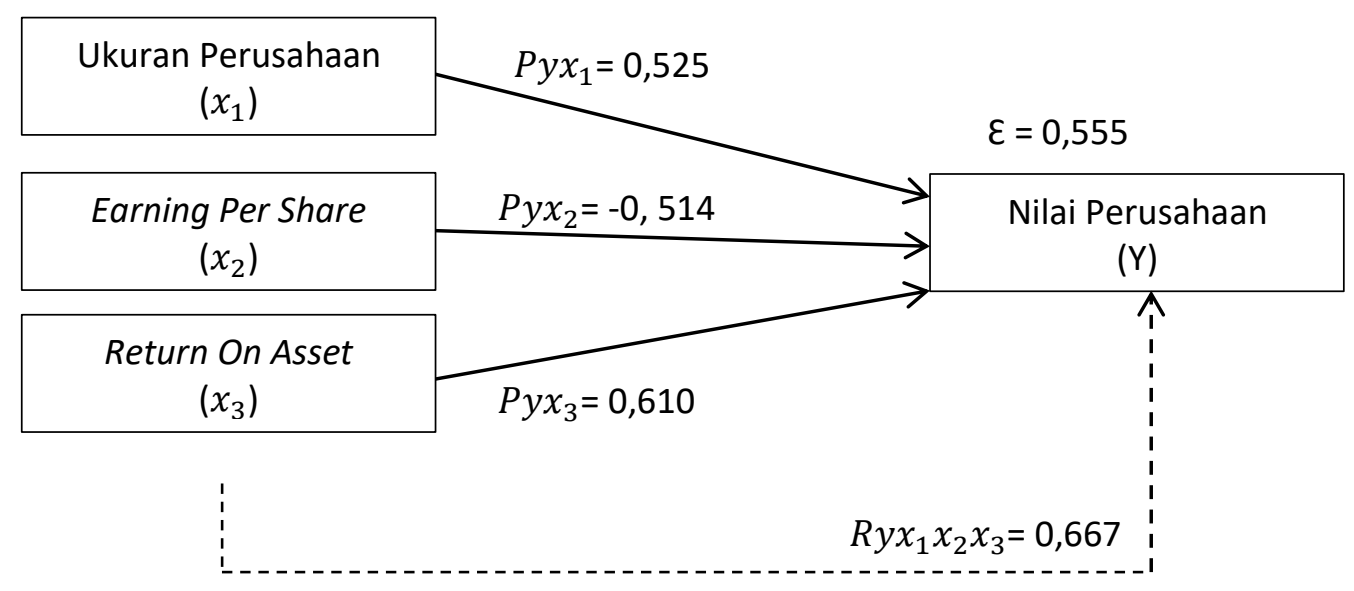

Hipotesis penelitian pertama ini menunjukan bahwa 『Ryx】_1 x_2 x_3 $=0,667$ dengan $p$-value $0,001<$ alpha 0,05 . Sehingga $H_{-}$0 ditolak yang artinya terdapat pengaruh signifikan antara ukuran perusahaan, earning per share dan return on asset terhadap nilai perusahaan sub sektor makanan dan minuman yang terdaftar di Bursa Efek Indonesia.

Hipotesis penelitian kedua menunjukan bahwa 『Pyx $\rrbracket_{-} 1=0,525$ dengan p-value 0,002 $<$ alpha 0,05. Sehingga H_0 ditolah yang artinya terdapat pengaruh ukuran perusahaan positif dan signifikan terhadap nilai perusahaan sub sektor makanan dan minuman yang terdaftar di Bursa Efek Indonesia. 
Hipotesis penelitian ketiga menunjukan bahwa [Pyx $\ 2=-0,514$ dengan p-value 0,003 < alpha 0,05. Sehingga $H_{-}$0 ditolak yang artinya terdapat pengaruh negatif dan signifikan terhadap nilai perusahan sub sektor makanan dan minuman yang terdaftar di Bursa Efek Indonesia.

Hipotesis keempat menunjukan bahwa [Pyx $\_3=0,610$ dengan p-value $0,000<$ alpha 0,05. Sehingga $H_{-} 0$ ditolak yang artinya terdapat pengaruh positif dan signifikan terhadap nilai perusahaan sub sektor makanan dan minuman yang terdaftar di Bursa Efek Indonesia.

Nilai $\mathrm{R}^{\wedge} 2$ pada penelitian ini sebesar 0,445. Sehingga hasil ini menunjukan bahwa besar sumbangan pengaruh dari ukuran perusahaan, earning per share dan return on asset terhadap nilai perusahaan sebesar $44,5 \%$. Sedangkan sisanya sebesar $0,555 \quad(55,5 \%)$ dipengaruhi oleh variabel lain yang tidak diteliti dalam penelitian ini.

Berdasarkan hasil yang diperoleh, menunjukan bahwa pada penelitian ini terdapat pengaruh signifikan secara simultan antara ukuran perusahaan, earning per share dan return on asset terhadap nilai perusahaan sub sektor makanan dan minuman yang terdaftar di Bursa Efek Indonesia. Hal ini mengandung arti bahwa apabila terjadi peningkatan pada variabel ukuran perusahaan, earning per share dan return on asset maka akan memberikan dampak terhadap peningkatan nilai perusahaan pada sub sektor makanan dan minuman yang terdaftar di Bursa Efek Indonesia.

Menurut Musayyana dkk (2019) bahwa, apabila ukuran perusahaan, earning per share dan return on asset mengalami peningkatan maka hal tersebut dapat memberikan pengaruh terhadap meningkatkan nilai perusahaan. Teori ini didukung dan sejalan dengan penelitian yang dilakukan oleh Sukma dan Erawati (2014) yang dalam hasilnya menyatakan bahwa variabel ukuran perusahaan, earning per share, profitabilitas dan leverage berpengaruh secara simultan terhadap nilai perusahaan.

Dalam hasil penelitian ini menunjukan bahwa terdapat pengaruh positif dan signifikan secara parsial dari ukuran perusahaan terhadap nilai perusahaan sub sektor makanan dan minuman yang terdaftar di Bursa Efek Indonesia. Artinya bahwa semakin besar ukuran suatu perusahaan maka perusahaan tersebut mampu untuk mengelola semua aset yang dimilikinya untuk meningkatkan tujuan perusahaan yakni meningkatkan nilai perusahaan dengan maksimal. Prasetyorini (2013), menjelaskan bahwa semakin besar ukuran atau skala perusahaan maka akan semakin besar peluang perusahaan untuk mendapatkan sumber dana dari berbagai pihak, baik internal maupun dari pihak eksternal sehingga hal ini menjadi potensi pada perusahaan untuk meningkatkan nilai perusahaan Hasil ini sejalan dengan penelitian yang dikemukakan oleh Rachmawati dan Pinem (2015) bahwa ukuran perusahaan memiliki pengaruh positif dan signifikan terhadap nilai perusahaan.

Hasil penelitian ini menunjukan bahwa terdapat pengaruh negatif dan signifikan pada earning per share terhadap nilai perusahaan sub sektor makanan dan minuman yang terdaftar di Bursa Efek Indonesia. Hal ini berarti bahwa setiap kenaikan pada rasio earning per share tidak selalu membantu memaksimalkan nilai perusahaan. Menurut Kasmir (2010), earning per share (EPS) merupakan rasio yang digunakan untuk mengukur kemampuan manajemen perusahaan dalam menghasilkan laba per lembar sahamnya dan diberikan kepada pemegang saham atau investor sehingga hal tersebut dapat menarik minat para investor. Hasil penelitian ini didukung oleh Kurniawati (2016) yang menemukan bahwa earning per share berpengaruh negatif dan signifikan terhadap nilai perusahaan.

hasil penelitian ini menunjukan bahwa variabel return on asset berpengaruh positif dan signifikan terhadap nilai perusahaan sub sektor makanan dan minuman yang terdaftar di Bursa Efek Indonesia. Return on asset merupakan bagian dari pada rasio profitabilitas yang bertujuan untuk mengukur sejauh mana kemampuan perusahaan dalam mengelola keseluruhan dana yang ditanamkan dalam operasi perusahaan dengan tujuan menghasilkan 
laba dengan memanfaatkan aktiva yang dimilikinya. Semakin besar ROA yang dimiliki maka semakin besar laba yang diperoleh. Perusahaan yang memiliki tingkat laba yang tinggi dapat membuka peluang bagi para investor untuk melakukan kegiatan investasi. Apabila ROA pada perusahaan semakin meningkat maka para stakeholders yakni kreditur, supplier, dan investor akan menilai sejauh mana perusahaan mampu memperoleh laba dari penjualan dan investasi yang dimiliki perusahaan sehingga dapat melakukan investasi dan hal tersebut mampu mendorong pencapaian tujuan perusahaan yakni meningkatkan nilai perusahaan (Rinnaya dkk, 2016). Hasil penelitian ini didukung oleh Rosikah dkk (2018) yang menemukan bahwha, rasio profitabilitas yang diproyeksikan dengan return on asset memiliki pengaruh positif dan signifikan terhadap nilai perusahaan. semakin tinggi keuntungan yang dimiliki oleh perusahaan maka hal ini berpengaruh pada meningkatnya nilai perusahaan.

\section{Simpulan dan Saran}

Berdasarkan hasil pengujian data yang telah dijelaskan diatas maka dapat ditarik beberapa kesimpulan sebagai berikut: 1) Ukuran perusahaan, earning per share dan return on asset berpengaruh positif dan signifikan secara simultan terhadap nilai perusahaan sub sektor makanan dan minuman yang terdaftar di Bursa Efek Indonesia tahun 2016 - 2018. 2) Ukuran perusahaan berpengaruh positif dan signifikan secara parsial terhadap nilai perusahaan sub sektor makanan dan minuman yang terdaftar di Bursa Efek Indonesia tahun 2016 - 2018. 3) Earning per share berpengaruh negatif dan signifikan secara parsial terhadap nilai perusahaan sub sektor makanan dan minuman yang terdaftar di Bursa Efek Indonesia tahun 2016 - 2018. 4) Return on asset berpengaruh positif dan signifikan secara parsial terhadap nilai perusahaan sub sektor makanan dan minuman yang terdaftar di Bursa Efek Indonesia tahun $2016-2018$.

Berdasarkan hasil penelitian dan pembahasan serta kesimpulan yang telah dijelaskan diatas, maka peneliti mengajukan beberapa saran sebagai berikut.1)BagiPerusahaan, berdasarkan hasil penelitian ini maka diharapkan kepada perushaan sub sektor makanan dan minuman yang terdaftar di Bursa Efek Indonesia untuk lebih meningkatkan nilai perusahan dengan memperhatikan beberapa faktor yakni ukuran perusahaan, laba perlembar saham (earning per share) dan return on asset. 2) Bagi investor, berdasarkan hasil pada penelitian ini maka diharapkan kepada para investor agar penelitian dapat menjadi bahan informasi dalam pengambilan keputusan untuk melakukan kegiatan penanaman modal pada perusahaan manapun. Investor diharapkan dapat mempertimbangkan dan menganalis mengenai nilai perusahaan yang ada dengan memperhatikan ukuran perusahaan, rasio earning per share dan rasio return on asset sehingga menjadi gambaran dalam memilih perusahaan yang baik untuk melakukan kegiatan penanaman modal. 3) Bagi peneliti selanjutnya, berdasarkan hasil penelitian ini, maka diharapkan bagi para peneliti selanjutnya untuk melakukan pengembangan terhadap penelitian ini. Diharapkan bagi peneliti selanjutnya untuk melakukan penelitian atau pengujian terhadap variabel lain yang ditafsirkan juga dapat mempengaruhi nilai perusahaan sehingga memperoleh hasil yang baik dan relevan dalam hal berpengaruh terhadap nilai perusahaan. peneliti juga berharap agar pada penelitian selanjutnya tidak hanya menggunakan perusahaan sub sektor makanan dan minuman yang terdaftar di Bursa Efek Indonesia tetapi juga dilakukan di berbagai macam perusahaan yang ada baik yang terdaftar di Bursa Efek Indonesia maupun yang tidak terdaftar.form.

\section{Daftar Pustaka}

Aniela eksinda, D eannes Isynuwardhana, S.E., M.M. Annisa Nurbaiti, S.E., M.Si. 2017. Pengaruh Profitabilitas, Leverage, dan Ukuran Perusahaan Terhadap Nilai Perusahaan(Studi pada Perusahaan Manufaktur Sub Sektor Barang dan Konsumsi 
yang Terdaftar di Bursa Efek Indonesia Periode 2012-2015) . e-Proceeding of Management : Vol.4, No.1 ISSN : 2355-9357, 542-549.

Ayu Sri Mahatma Dewi, Ary Wirajaya. 2013."Pengaruh Struktur Modal, Profitabilitas dan Ukuran Perusahaan Pada Nilai Perusahaan ." E-Jurnal Akuntansi Universitas Udayana , Vol.4.No.2, ISSN: 2302-8556, 358-372.

Bayu Irfandi Wijaya .B. Panji Sedana. 2015.Pengaruh Profitabilitas Terhadap Nilai Perusahaan (Kebijakam dividen dan Kesempatan investasi Sebagai Variabel Mediasi) ." E-Jurnal Manajemen Unud, Vol.4, No.12: 4477-4500.

Chuswatul Chasanah, E. Kiswara. 2017. Pengaruh Laba Per Lembar Saham,Nilai Buku Per Lembar Saham, dan Transaksi Abnormal Pihak Berelasi Terhadap Relevansi Nilai Dengan Mekanisme Tata Kelola Perusahaan Sebagai Variabel Moderasi. JOURNAL OF ACCOUNTING Volume 6, Nomor 3, ISSN(Online): 2337-3806, 16 - 25.

Dr. Harmono, S.E., M.Si. 2016 .Manajemen Keuangan,Berbasis Balance Scorecard, Pendekatan Teori,Kasus, dan Riset Bisnis. jakarta: PT. Bumi Aksara.

Eksandy, A. (2017). Pengaruh Ukuran Perusahaan, Solvabilitas,Profitabilitas dan Komite Audit Terhadap Audit Delay. Competitive Jurnal Akuntansi dan Keuangan, Vol.1, No.2, ISSN 2503-2518, 287-295.

Fatimatus Zuhairoh, T. S. (2019). Relevansi Nilai Inkremental Arus Kas Operasi dan Laba (Earning After Tax) Terhadap Harga Saham. Jurnal Akademi Akuntansi 2019 Volume 2 No. 2, ISSN 1098-6596, 81-92.

Gerald Edsel Yermia Egam, Ventje Ilat, Sonny Pangerapan. 2017. Pengaruh Return On Asset (ROA), Return On Equity (ROE), Net Profit Margin (NPM), dan Earning Per Share (EPS) Terhadap Harga Saham Perusahaan Yang Tergabung Dalam Indeks LQ45 DI Bursa Efek Indonesia Periode Tahun 2013-2015 . Jurnal EMBA Vol.5 No.1 , 105-114.

I Gusti Ngurah Gede Rudangga, Gede Merta Sudiarta.2016. Pengaruh Ukuran Perusahaan, Leverage, Dan Profitabilitas Terhadap Nilai Perusahaan . E-Jurnal Manajemen Unud, Vol. 5, No.7, ISSN : 2302-8912, 4394 - 4422 .

Kasmir, S.E.,M.M. 2010. Pengantar Manajemen Keuangan. Jakarta: Kencana Prenanda Media Group.

Sulistyono, Wiwik S. (2017). Peramalan Produksi dengan Metode Regresi Linier Berganda. Prozima, Vol 1, No.2,E. ISSN. 2541-5115, 82-89.

Vera Handayani, Mayasari.2018. Analisis Pengaruh Hutang Terhadap Laba Bersih Pada PT. Kereta Api Indonesia (PERSERO) . Jurnal Riset Akuntansi \& Bisnis Vol. 18 No. ISSN : 1693-7597, 39-50.

Wanti, Ferra Kusuma Purbo.2012. Kemampuan Laba Bersih, Arus Kas Operasi, dan Rasio Piutang Untuk Mempengaruhi Arus Kas Masa Mendatang Pada Perusahaan Food And Beverage di BEI .Berkala Ilmiah Mahasiswa Akuntansi - Vol. 1, NO. 3, , 36-41. 
Zuhria Hasania, Sri Murni, Yunita Mandagie.2016. Pengaruh Current Ratio, Ukursan Perusahaan, Struktur Modal, dan Return On Asset Terhadap Nilai Perusahaan Pada Perusahaan Farmasi Yang Terdaftar di Bursa Efek Indonesia Periode 2011 - 2014. Jurnal Berkala Ilmiah Efisiensi Volume 16 No. 03 , 133-144 